\title{
Black gram (Vigna Mungo L.) foliage supplementation to crossbred cows: effects on feed intake, nutrient digestibility and milk production
}

\author{
Avijit Dey $^{1,2, *}$, Partha Sarathi De ${ }^{3}$, and Prabir Kumar Gangopadhyay ${ }^{1}$
}

\section{* Corresponding Author: Avijit Dey Tel: +91-1662-281619, Fax: +91-1662-275004 E-mail: avijitcirb@gmail.com}

'Regional Research Sub-station and Krishi Vigyan Kendra, Uttar Banga Krishi Viswavidyalaya, Malda 732205, India

2 Division of Animal Nutrition and Feed Technology, ICAR- Central Institute for Research on Buffaloes, Hisar 125001, India

${ }^{3}$ Department of Botany, Sonamukhi College, University of Burdwan, Bankura 722207, India

Submitted Apr 11, 2016; Revised May 23, 2016; Accepted May 30, 2016
Objective: An experiment was conducted to examine the effect of dietary supplementation of dried and ground foliage of black gram (Vigna mungo L.) on feed intake and utilization, and production performance of crossbred lactating cows.

Methods: Eighteen lactating crossbred (Bos taurus $\times$ Bos indicus) cows (body weight $330.93 \pm$ $10.82 \mathrm{~kg}$ ) at their second and mid lactation (milk yield $6.77 \pm 0.54 \mathrm{~kg} / \mathrm{d}$ ) were randomly divided into three groups of six each in a completely randomized block design. Three supplements were formulated by quantitatively replacing 0,50 , and 100 per cent of dietary wheat bran of concentrate mixture with dried and ground foliage of black gram. The designated supplement was fed to each group with basal diet of rice straw (ad libitum) to meet the requirements for maintenance and milk production. Daily feed intake and milk yield was recorded. A digestion trial was conducted to determine the total tract digestibility of various nutrients.

Results: The daily feed intake was increased $(\mathrm{p}<0.05)$ with the supplementation of black gram foliage. Although the digestibility of dry matter, organic matter, crude protein, and ether extract did not vary $(p>0.05)$, the fibre digestibility was increased $(p<0.05)$, which ultimately improved $(\mathrm{p}<0.05)$ the total digestible nutrients content of composite diet. Although, the average milk yield ( $\mathrm{kg} /$ animal/d) and composition did not differ ( $\mathrm{p}>0.05)$ among the groups, milk yield was increased by 10 per cent with total replacement of wheat bran in concentrate mixture with of black gram foliage. The economics of milk production calculated as feed cost per kg milk yield (INR 10.61 vs 7.98) was reduced by complete replacement of wheat bran with black gram foliage.

Conclusion: Black gram foliage could be used as complete replacement for wheat bran in concentrate mixture of dairy cows in formulating least cost ration for economic milk production in small holders' animal production.

Keywords: Black Gram Foliage, Intake, Nutrient Digestibility, Milk Yield, Cows

\section{INTRODUCTION}

Small holders' production rely on feeding of low-quality roughages, agricultural crop-residues and industrial by-products which contain high level of ligno-cellulosic materials and thus, less palatable, resulting lower feed intake. Rumen fermentation is largely affected by fermentable nitrogen and fibre along with some other associated factors $[1,2]$. One of the strategies to manipulate the rumen environment is supplementation, particularly when poor quality roughages are fed. The principal objective of supplementation is to increase the supply of nutrients, mainly energy and protein, such as to create favourable conditions in the rumen which result in enhanced fermentation of basal roughage and thus, improve animal performance [3,4]. Use of unconventional feed resources to develop least cost ration has been increasing for sustainable 
livestock farming. Black gram (Vigna mungo L.) is a major important pulse cultivated not only in India, but also in other Asian countries and some parts of Africa [5]. A large quantity of pods and foliage are obtained as by-product during collection of seeds, which could be utilized as supplement to livestock $[6,7]$. This study, therefore, aimed to assess the effect of dietary supplementation of black gram foliage on feed intake, nutrient digestibility and production performance of crossbred cows fed rice straw based diet.

\section{MATERIALS AND METHODS}

The experiment was conducted at Malda district in West Bengal Province of India. Mixed farming involving crops and livestock integration and feeding of agricultural byproducts has been a way of life in this region. A huge quantity of black gram foliage has been available as byproduct during the harvesting of crop for feeding to ruminants.

\section{Animals and diets}

Eighteen lactating crossbred (Bos taurus $\times$ Bos indicus) cows (body weight [BW] $330.93 \pm 10.82 \mathrm{~kg}$ ) at their second and mid lactation (milk yield $6.77 \pm 0.54 \mathrm{~kg} / \mathrm{d}$ ) were randomly allocated into three dietary treatments in a completely randomized block design. Prior to start of the experiment the cows were treated with broad-spectrum anthelmintic (Albendazole suspension [Smith Kline Phermaceuticals Limited, India] at $2 \mathrm{~mL} / 10 \mathrm{~kg} \mathrm{BW}$ ). Three supplements were formulated replacing wheat bran by 0,50 , and 100 per cent with dried and ground foliage of black gram in concentrate mixture (Table 1). The supplements were designated as control (CON), 50\% black gram foliage (BGF-50) and $100 \%$ black gram foliage (BGF-100) and fed to crossbred

Table 1. Ingredients and chemical composition of supplements, black gram foliage and wheat bran

\begin{tabular}{|c|c|c|c|c|c|}
\hline \multirow{2}{*}{ Constituents } & \multicolumn{3}{|c|}{ Supplements } & \multirow{2}{*}{$\begin{array}{l}\text { Black gram } \\
\text { foliage }\end{array}$} & \multirow{2}{*}{$\begin{array}{c}\text { Wheat } \\
\text { bran }\end{array}$} \\
\hline & CON & BGF-50 & BGF-100 & & \\
\hline \multicolumn{6}{|l|}{ Ingredients (kg) } \\
\hline Maize grain & 25.0 & 25.0 & 25.0 & - & - \\
\hline Mustard cake & 30.0 & 30.0 & 30.0 & - & - \\
\hline Wheat bran & 43.0 & 21.5 & - & - & - \\
\hline Black gram foliage & - & 21.5 & 43.0 & - & - \\
\hline Mineral mixture & 1.0 & 1.0 & 1.0 & - & - \\
\hline Common salt & 1.0 & 1.0 & 1.0 & - & - \\
\hline \multicolumn{6}{|c|}{ Chemical composition (\% DM) } \\
\hline $\mathrm{OM}$ & 95.8 & 94.1 & 92.3 & 87.2 & 91.6 \\
\hline $\mathrm{CP}$ & 18.3 & 18.4 & 18.7 & 15.5 & 14.8 \\
\hline $\mathrm{EE}$ & 5.2 & 5.1 & 5.0 & 2.9 & 3.2 \\
\hline Total Ash & 4.2 & 5.9 & 7.7 & 12.8 & 8.4 \\
\hline NDF & 28.4 & 29.7 & 31.8 & 41.6 & 37.2 \\
\hline ADF & 10.6 & 14.1 & 18.3 & 27.1 & 11.5 \\
\hline
\end{tabular}

$\mathrm{DM}$, dry matter; OM, organic matter; $\mathrm{CP}$, crude protein; $\mathrm{EE}$, ether extract; NDF, neutral detergent fibre; $A D F$, acid detergent fibre. cows along with basal diet of rice straw (ad libitum) to meet the requirements [8] for maintenance and milk production. Black gram foliage was collected during the thrashing of matured pods for collection of seeds and incorporated in the respective supplements. The amount of supplements offered to individual cows was adjusted weekly as per the milk yield of each animal to meet the requirement.

\section{Experimental procedure}

The daily allowance of the supplements was offered in two equal meals in the morning $(06: 00 \mathrm{~h})$ and in the afternoon (15:00 h) during the time of milking along with rice straw as total mixed ration. Residues remaining were weighed $24 \mathrm{~h}$ post-feeding to ascertained daily feed consumption. The feeding trial was carried out for 85 days duration including the first 15 days for adaptation and subsequent 70 days for data recording. Milking was done twice daily (6:00 $\mathrm{h}$ and 15:00 h) and daily milk yield of individual cows were recorded throughout the experiment. Milk samples (50 mL each) from each cow was drawn once a week for analysis of milk composition and stored at $4^{\circ} \mathrm{C}$ after adding 2 to 3 drops of potassium dichromate as a preservative, until further analysis.

A digestion trial of 6 days duration was conducted towards the end of experimental feeding. Samples of feed offered and refused were collected daily. The daily feed intake and faecal output from individual cows were recorded. A suitable subsample of faeces was collected and dried at $80^{\circ} \mathrm{C} \pm 2^{\circ} \mathrm{C}$ for $24 \mathrm{~h}$ in a forced-draft oven for dry matter (DM) estimation. Pooled samples ( 6 days for each animal) were ground and stored for chemical analysis.

\section{Chemical and statistical analyses}

Samples of feeds, residues and faeces were milled to pass through a $1 \mathrm{~mm}$ sieve and analyzed for proximate principles following the methods of the AOAC [9] to determine DM by oven drying method (934.01), organic matter (OM) by muffle furnace incineration (967.05), crude protein (CP), by kjeldahl method (984.13), ether extract (EE) (920.39), ash (942.05). Neutral detergent fibre (NDF) and acid detergent fibre (ADF) were estimated by the methods of Van Soest et al [10]. Milk samples were warmed in water bath at $38^{\circ} \mathrm{C}$ and mixed for homogenous solution and analyzed for total solids, total ash, total protein and fat content [11].

The results obtained were subjected to analysis of variance using the general linear models procedures of the SPSS 11.0 software and treatment means were ranked using Duncan's multiple range tests according to Snedecor and Cochran [12].

\section{RESULTS AND DISCUSSION}

Black gram foliage contained comparable crude protein with wheat bran which made the experimental supplements iso-ni- 
trogenous (Table 1). However, higher fibre content of the supplements could be attributable to more cell wall constituents present in BGF, which usually present in the leaf meal [13-15]. The chemical composition of feed ingredients and supplements offered to lactating crossbrewd cows were within the normal range and comparable to values reported for Indian feeds and fodder [16].

Daily intake $\left(\mathrm{g} / \mathrm{kg} \mathrm{W}^{0.75}\right)$ of rice straw as well as total dry matter (Table 2$)$ was increased significantly $(\mathrm{p}<0.05)$ with the supplementation of BGF, irrespective of levels. The DM intake of lactating cows ranges from 81 to $121 \mathrm{~g} / \mathrm{kg} \mathrm{W}^{0.75}[8,17]$. In the present study, the cows had DM intake of 118 to $136 \mathrm{~g} / \mathrm{kg} \mathrm{W}^{0.75}$, which clearly indicates that the supplements were palatable. The increased total DM intake due to greater straw intake in BGF supplemented cows could be attributable to positive associative effects of BGF in utilization of rice straw by modulating rumen fermentation [18], which also significantly $(\mathrm{p}<0.05)$ increased fibre digestibility. Our study also gets support from the observation of Islam et al [19] that supplementation of legume forage increased the DM intake.

Although, the digestibility coefficient of DM, OM, CP, and EE were similar ( $p>0.05)$, the NDF and ADF digestibility was

Table 2. Feed Intake, nutrient digestibility and plane of nutrition of crossbred cows supplemented with black gram foliage

\begin{tabular}{|c|c|c|c|c|c|}
\hline \multirow{2}{*}{ Attributes } & \multicolumn{3}{|c|}{ Treatments ${ }^{1)}$} & \multirow{2}{*}{ SEM } & \multirow{2}{*}{$p$ value } \\
\hline & CON & BGF-50 & BGF-100 & & \\
\hline \multicolumn{6}{|l|}{ Body weight } \\
\hline $\mathrm{Kg}$ & 323.3 & 337.6 & 331.9 & 12.8 & 0.713 \\
\hline Metabolic size $\left(\mathrm{W}^{0.75}\right)$ & 76.2 & 78.8 & 77.8 & 1.73 & 0.851 \\
\hline \multicolumn{6}{|l|}{ Intake $\left(\mathrm{g} / \mathrm{kg} \mathrm{W} \mathrm{W}^{0.75}\right)$} \\
\hline Concentrate & 46.7 & 47.7 & 48.8 & 1.34 & 0.752 \\
\hline Rice straw & $72.1^{\mathrm{a}}$ & $85.2 b$ & $87.2^{b}$ & 4.14 & 0.023 \\
\hline Total DM & $118.8^{\mathrm{a}}$ & $132.9^{b}$ & $136.0^{b}$ & 4.69 & 0.019 \\
\hline \multicolumn{6}{|l|}{ Nutrient digestibility (\%) } \\
\hline DM & 61.3 & 61.8 & 62.4 & 1.92 & 0.910 \\
\hline $\mathrm{OM}$ & 64.8 & 67.6 & 68.9 & 1.76 & 0.861 \\
\hline $\mathrm{CP}$ & 65.6 & 66.1 & 67.3 & 1.76 & 0.920 \\
\hline EE & 64.3 & 65.8 & 66.8 & 1.64 & 0.953 \\
\hline NDF & $53.3^{\mathrm{a}}$ & $54.6^{\mathrm{ab}}$ & $56.1^{b}$ & 1.92 & 0.042 \\
\hline ADF & $40.6^{\mathrm{a}}$ & $44.1^{\mathrm{ab}}$ & $46.2^{b}$ & 2.93 & 0.038 \\
\hline \multicolumn{6}{|l|}{ Nutrient density (\%) } \\
\hline DCP & 6.7 & 7.0 & 7.2 & 0.13 & 0.923 \\
\hline TDN & $59.6^{a}$ & $62.7^{\mathrm{ab}}$ & $64.3^{b}$ & 1.87 & 0.017 \\
\hline \multicolumn{6}{|c|}{ Nutrient Intake (g/kg W.75) } \\
\hline DCP & 8.2 & 8.3 & 8.3 & 0.47 & 0.901 \\
\hline $\operatorname{TDN}^{2)}$ & $65.9^{\mathrm{a}}$ & $72.4^{\mathrm{ab}}$ & $73.6^{b}$ & 3.69 & 0.016 \\
\hline
\end{tabular}

SEM, standard error of the mean; DM, dry matter; OM, organic matter; $C P$, crude protein; $E E$, ether extract; NDF, neutral detergent fibre; ADF, acid detergent fibre; $D C P$, digestible crude protein; TDN, total digestible nutrients; DOM, digestible organic matter. 1) CON, cows supplemented with control concentrate mixture (maize grain, 25\%; mustard cake, 30\%; wheat bran 43\%; mineral mixture and common salt, 1\% each); BGF50 , cows fed concentrate mixture containing $50 \%$ black gram foliage replacing wheat bran; BGF-100, cows fed concentrate mixture containing 100\% black gram foliage replacing wheat bran.

${ }^{2)}$ TDN calculated from DOM (1 kg DOM = $1.05 \mathrm{~kg}$ TDN; NRC, 1981).

${ }^{a, b}$ Mean bearing different superscript within a row differ significantly $(p<0.05)$. significantly $(\mathrm{p}<0.05)$ increased in BGF-100 supplemented cows. The nutrient density (\%) of composite diets and intake of total digestible nutrients $(\mathrm{TDN})\left(\mathrm{g} / \mathrm{kg} \mathrm{W}^{0.75}\right)$ were significantly $(\mathrm{p}<0.05)$ higher in cows fed BGF-100 supplement with comparable values between control and BGF-50 supplemented cows. The present results represent that all the experimental animals had enough nutrients (digestible crude protein and TDN) to meet the requirements for maintenance and milk production [8]. However, a trend in higher TDN content of diet in BGF-50 group animals with significant $(\mathrm{p}<0.05)$ increase in BGF-100 indicates better plane of nutrition of cows fed BGF supplemented diet. The associative effects between the feeds can modify the metabolic processes in the rumen, so that the response of an animal to a combination of feeds can differ from the balanced median values of its components considered individually. This kind of response can be synergistic or antagonistic with a possible impact in nutrient utilization by the animals. The possible associative effect of BGF supplementation on acceleration of the fibre digestion of rice straw and nutrient density of composite diet could be related to fulfilment of nutritional adequacy of fermentation due to supplementation of limiting amino acids and minerals through BGF, resulting stimulation of the fibrolytic activity and also to the possible presence of growth promoting factors [20,21].

Although, the average milk yield $(\mathrm{kg} / \mathrm{d})$ and composition did not differ ( $p>0.05)$ among the groups, milk yield was increased by 10 per cent in BGF-100 group animals with total replacement of wheat bran by BFG in concentrate mixture (Table 3), suggesting efficient utilization of feed nutrients in these animals. Continuous supply of energy and nitrogen for rumen microbes improved rumen fermentation for better utilization of fibrous feeds and could have provided additional volatile fatty acids for better milk production [19,22]. The cost of wheat bran and black gram foliage containing concentrates were (INR/quintal) $1,677,1,441$, and 1,204, respectively. The cost-benefit analysis of effect of wheat bran revealed that the cost of concentrate for lactating cows could be reduced by INR 473/quintal, if wheat bran is fully replaced by black gram foliage. The feeding cost per kg milk production was reduced (INR 10.61 vs 7.98 ) in cows fed BGF-100 diet as compared to control.

Present study suggests that the locally available agro-industrial byproducts viz. Black gram foliage could be incorporated in formulating least cost ration for economic milk production in small holders' dairy production without any adverse effect on feed intake, nutrient utilization and production performance of crossbred cows.

\section{CONFLICT OF INTEREST}

We certify that there is no conflict of interest with any financial organization regarding the material discussed in the manuscript. 
Table 3. Effect of dietary supplementation of black gram foliage on milk yield, milk composition and economics in dairy cows

\begin{tabular}{|c|c|c|c|c|c|}
\hline \multirow{2}{*}{ Attributes } & \multicolumn{3}{|c|}{ Treatments $^{1)}$} & \multirow{2}{*}{ SEM } & \multirow{2}{*}{$\mathrm{p}$ value } \\
\hline & CON & BGF-50 & BGF-100 & & \\
\hline \multicolumn{6}{|l|}{ Milk yield } \\
\hline $\mathrm{kg} / \mathrm{d}$ & 6.4 & 6.9 & 7.0 & 0.8 & 0.751 \\
\hline $4 \%$ FCM $(\mathrm{kg} / \mathrm{d})$ & 6.2 & 6.8 & 6.9 & 0.5 & 0.824 \\
\hline \multicolumn{6}{|l|}{ Milk composition (\%) } \\
\hline Fat & 3.89 & 3.92 & 3.90 & 0.1 & 0.983 \\
\hline Protein & 3.62 & 3.64 & 3.69 & 0.02 & 0.991 \\
\hline Total Ash & 0.76 & 0.75 & 0.77 & 0.01 & 0.990 \\
\hline SNF & 8.82 & 8.94 & 9.02 & 0.06 & 0.894 \\
\hline Total solids & 12.74 & 12.91 & 12.94 & 0.07 & 0.945 \\
\hline \multicolumn{6}{|l|}{ Yield (g/d) } \\
\hline Fat & 249.10 & 270.35 & 274.94 & 17.32 & 0.675 \\
\hline Protein & 232.43 & 252.12 & 257.90 & 9.52 & 0.753 \\
\hline \multicolumn{6}{|c|}{ Economics of feeding ${ }^{2)}($ INR/d) } \\
\hline Cost of supplement & 59.68 & 54.16 & 45.71 & - & - \\
\hline Cost of rice straw & 8.24 & 10.07 & 10.18 & - & - \\
\hline Total feed cost & 67.92 & 64.23 & 55.89 & - & - \\
\hline Feed cost $/ \mathrm{kg}$ milk yield & 10.61 & 9.31 & 7.98 & - & - \\
\hline
\end{tabular}

SEM, standard error of the mean; FCM, fat corrected milk; SNF, solid not fat; INR, Indian Rupees.

1) CON, cows supplemented with control concentrate mixture (maize grain, 25\%; mustard cake, 30\%; wheat bran 43\%; mineral mixture and common salt, 1\% each); BGF50 , cows fed concentrate mixture containing $50 \%$ black gram foliage replacing wheat bran; BGF-100, cows fed concentrate mixture containing 100\% black gram foliage replacing wheat bran.

${ }^{2)}$ The unit cost (INR/quintal) of supplements were 1,677, 1,441, and 1,204 for CON, BGF-50, and BGF-100, respectively. The cost (INR/quintal) of rice straw and black gram foliage were 150 and 300 , respectively.

\section{ACKNOWLEDGMENTS}

The work was supported by the National Agricultural Innovation Project (NAIP) and Indian Council of Agricultural Research (ICAR). The necessary facilities for conducting this study were provided by the Uttar Banga Krishi Viswavidyalaya (UBKV).

\section{REFERENCES}

1. Leng R, Preston T. Nutritional strategies for the utilization of agro-industrial by-products by ruminants and extension of the principles and technologies to the small farmer in Asia. In: New strategies for improving animal production for human welfare: proceedings/the Fifth World Conference on Animal Production, August 14-19, 1983; 1983: Tokyo, Japan: Japanese Society of Zootechnical Science, 1983.

2. Ma T, Tu Y, Zhang N, Deng K, Diao Q. Effect of the ratio of nonfibrous carbohydrates to neutral detergent fiber and protein structure on intake, digestibility, rumen fermentation, and nitrogen metabolism in lambs. Asian-Australa J Anim Sci 2015;28:141926.

3. Urdaneta $\mathrm{AB}$, Fondevila $\mathrm{M}$, Balcells J, Dapoza C, Castrillo C. In vitro microbial digestion of straw cell wall polysaccharides in response to supplementation with different sources of carbohydrates. Crop and Pasture Sci 2000;51:393-400.

4. Wanapat M, Kang S, Polyorach S. Development of feeding systems and strategies of supplementation to enhance rumen fermentation and ruminant production in the tropics. J Anim Sci Biotechnol 2013;4:32.

5. CSIR. A dictionary of Indian raw materials \& industrial products. Raw materials. In: Research CoSaI, editor. The Wealth of India. New Delhi: Council of Scientific and Industrial Research; 1976. p. 591.

6. Jensen PCM. Vigna mungo (L.) Hepper. In: Brink M and Belay G, editors. Record from Protabase. PROTA (Plant Resources of Tropical Africa/Ressources végétales de l'Afrique tropicale), Wageningen, Netherlands; 2006.

7. Arulnathan N, Murugan M, Balakrishnan V. Proximate principles, Fibre fraction and Mineral content of Black gram husk (Vigna mungo). Int J Livest Res 2013;3:24-30.

8. Kearl LC. Nutrient requirements of ruminants in developing countries: International Feedstuffs Institute; 1982.

9. AOAC. Official Methods of Analysis. Wasington, DC: Association of Official Analytical Chemists; 1995.

10. Van Soest PV, Robertson J, Lewis B. Methods for dietary fiber, neutral detergent fiber, and nonstarch polysaccharides in relation to animal nutrition. J Dairy Sci 1991;74:3583-97.

11. ISI. Chemical analysis of milk, part II. Indian Standards Methods of test for dairy industry. New Delhi, India: Indian Standards Institute; 1961.

12. Snedecor GW, Cochran WC. Statistical Methods. 8th ed. New Delhi, India: East West Press Pvt. Ltd; 1994.

13. Krishnamoorthy U, Soller H, Steingass H, Menke K. Energy and protein evaluation of tropical feedstuffs for whole tract and ruminal digestion by chemical analyses and rumen inoculum studies in vitro. Anim Feed Sci Technol 1995;52:177-88.

14. Dey A, Dutta N, Sharma K, Pattanaik AK. Effect of dietary inclusion of Ficus infectoria leaves as a protectant of proteins on the performance of lambs. Small Rumin Res 2008;75:105-14.

15. Dey A, De PS. Influence of condensed tannins from Ficus bengalensis leaves on feed utilization, milk production and antioxidant status of crossbred cows. Asian-Australas J Anim Sci 2014;27: 342-8.

16. Ranjhan SK. Animal nutrition and feeding practices. 6 ed. New Delhi, India: Vikas Publishing House Pvt. Ltd; 2004.

17. Dey A, Dutta N, Sharma K, Pattanaik AK. Response of dairy cows to dietary supplementation of condensed tannins through Ficus infectoria leaves. Indian J Anim Sci 2009;79:58.

18. Dey A, Paul SS, Pandey P, Rathore R. Potential of Moringa oleifera leaves in modulating in vitro methanogenesis and fermentation of wheat straw in buffalo. Indian J Anim Sci 2014;84:533-8.

19. Islam M, Sarker N, Islam M. Effect of feeding legume forage with straw supplementation on milk production at Pabna milk shed area. Asian-Australas J Anim Sci 1995;8:107-11.

20. Kumar S, Garg M. Nutritional evaluation of Black gram straw 
(Phaseolus Mungo) in Hurrah heifers. Indian J Anim Nutr 1995; 12:181-2.

21. Saran S, Singh R, Singh R, Rani SI, Singh K. Feed resources for rearing livestock in the Bundelkhand region of Uttar Pradesh.
Indian J Anim Sci 2000;70:526-9.

22. Krause DO, Denman SE, Mackie RI, et al. Opportunities to improve fiber degradation in the rumen: microbiology, ecology, and genomics. FEMS Microbiol Rev 2003;27:663-93. 